Journal of Applied Pharmaceutical Science Vol. 5 (09), pp. 062-067, September, 2015

Available online at http://www.japsonline.com

DOI: $10.7324 /$ JAPS.2015.50912

ISSN 2231-3354 (cc) BY-NC-SA

\title{
Chemical Constituents of Ixora philippinensis Merr.
}

\author{
Consolacion Y. Ragasa ${ }^{1,2 *}$, Maria Carmen S. Tan ${ }^{2}$, Dalton R. Fortin ${ }^{2}$, Chien-Chang Shen ${ }^{3}$ \\ ${ }^{1}$ Chemistry Department, De La Salle University Science \& Technology Complex Leandro V. Locsin Campus, Biñan City, Laguna, Philippines. ${ }^{2}$ Chemistry \\ Department, De La Salle University, 2401 Taft Avenue, Manila1004, Philippines. ${ }^{3}$ National Research Institute of Chinese Medicine, 155-1, Li-Nong St., \\ Sec. 2, Taipei, Taiwan.
}

\begin{tabular}{l} 
ARTICLE INFO \\
\hline Article history: \\
Received on: $11 / 06 / 2015$ \\
Revised on: 05/07/2015 \\
Accepted on: $26 / 08 / 2015$ \\
Available online: $27 / 09 / 2015$ \\
\hline Key words: \\
Ixora philippinensis, \\
Rubiaceae, syringaresinol, \\
pinoresinol, isoscopoletin, \\
lupeol, squalene, lutein, $\beta-$ \\
sitosterol, stigmasterol. \\
\hline
\end{tabular}

\section{INTRODUCTION}

Ixora philippinensis, a Philippine endemic ornamental plant, is locally known as white santan (Merril, 1910). The fruits of I. philippinensis are edible (Ysrael and Valkenburg, 1999). There are no reported studies on the chemical constituents and biological activities of I. philippinensis. However, a number of studies have been reported on a congener of the plant, Ixora coccinea L. which is cultivated throughout the Philippines as an ornamental plant. The flowers of this plant are used in the treatment of dysentery and leucorrhoea. A decoction of the flowers is used for the treatment of haemoptysis and catarrhal bronchitis (Quisumbing, 1978). Cytotoxic and antitumor principles (Latha and Panikar, 1998), chemoprotective (Latha and Panikar, 2001) and modulatory effects (Latha and Panikar, 1999) of the flowers on cisplatin-induced toxicity in mice have been reported. I. coccinea flowers yielded ursolic acid which was reported to be anti-genotoxic (Latha et al., 2001). 21,23-Epoxytirucall-7-en-3 $\beta$-ol also known as ixoroid, stigmast-5-en-3-O- $\beta$ D-glucoside, 5-O-caffeoylquinic acid and D-mannitol were

\footnotetext{
* Corresponding Author

Consolacion Ragasa, Chemistry Department, De La Salle University, 2401 Taft Avenue, Manila1004, Philippines.

Email: consolacion.ragasa@dlsu.edu.ph
}

isolated from the flowers of I. coccinea (Vesiani et al., 2012). The flowers of $I$. coccinea contain rutin, leucocyanadin glycoside, cyanadin-3-rutinoside and delphinidin monoglycoside, while the root contains octadecadienoic acid and methyl esters of palmatic, oleic, stearic and linolic acid (Kharat et al., 2013; Elumalai and Chinna, 2012). Lupeol isolated from the leaves of the plant showed anti-inflammatory and anti-mitotic activities (Reena et al., 1994). The major constituents of $I$. coccinea were reported to be lupeol, oleic acid, linolic acid, ursolic acid, oleanolic acid, stearic acid and $\beta$-sitosterol. A new triterpene, 17 $\beta$-dammara-12,20-diene-3 $\beta$-ol also known as ixorene was isolated from the leaves of I. coccinea, together with $\beta$-sitosterol, lupeol and D-mannitol (Ikram et al., 2013). The methanol extract of the leaves of $I$. coccinea yielded ixoratannin A-2, epicatechin, procyanidin A2, cinnamtannin B-1, kaempferol-7-O- $\alpha$-L-rhamnoside, kaempferol-3-O- $\alpha$-Lrhamnoside, quercetin-3-O- $\alpha$-L-rhamnopyranoside, and kaempferol-3,7-O- $\alpha$-L-dirhamnoside (Idowu et al., 2010). I. coccinea leaves afforded quercetin which exhibited high antioxidant activity (Bose et al., 2013). The major constituents of I. coccinea root were identified by GC-MS as hexadecanoic acid (7.38\%), 9-octadecenoic acid methyl ester (1.97\%), 2,6dimethoxyphenol (1.35\%), 13-docosenamide (1.31\%), 3,4,5trimethoxyphenol (1.24\%), and 4,8,12,16-tetramethy lheptadecan-4-olide (1.13\%) (Ghazaliet al., 2014). 

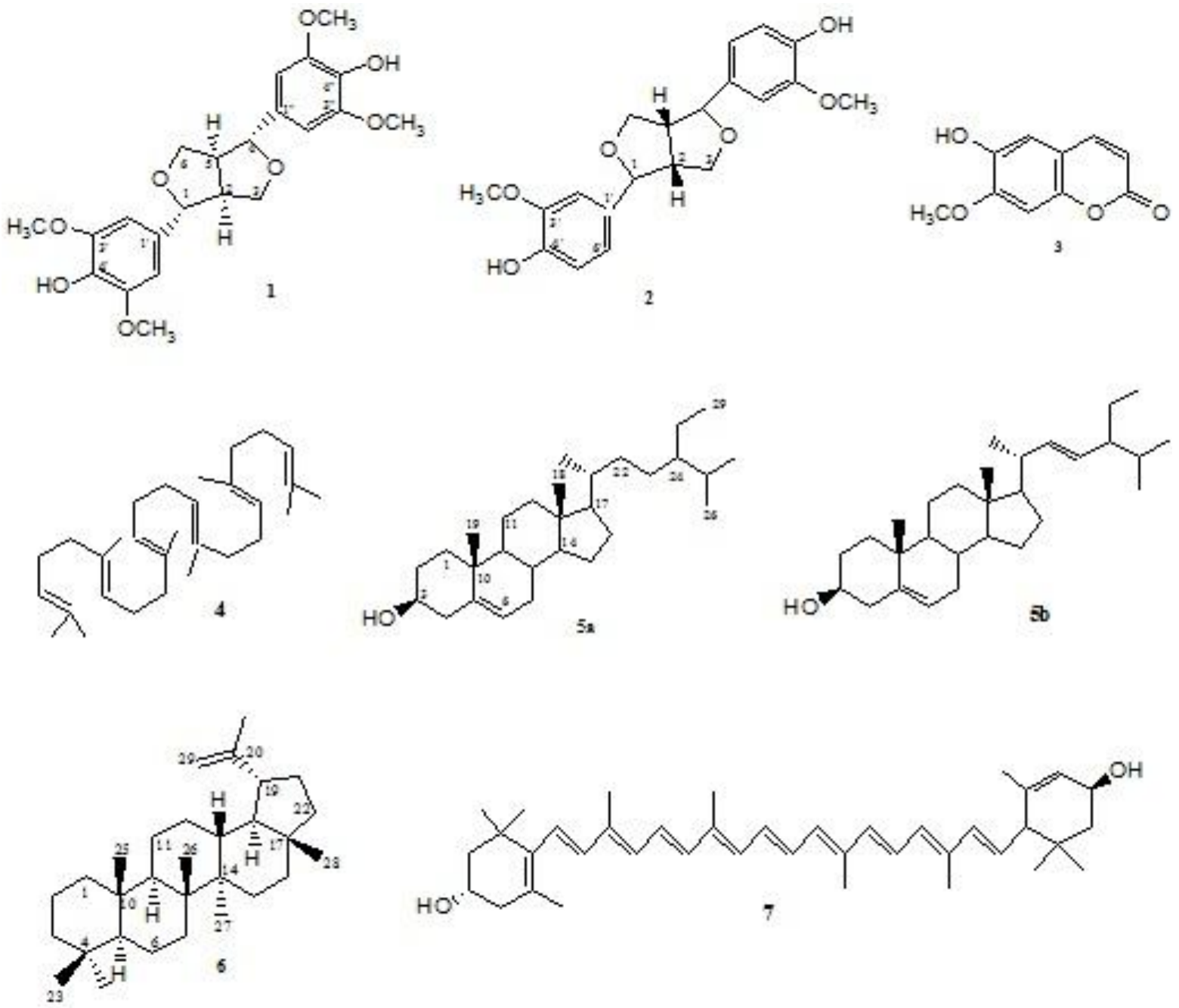

Chemical structures of syringaresinol (1), pinoresinol (2), isoscopoletin (3), squalene (4), $\beta$-sitosterol (5a), stigmasterol (5b), lupeol (6), and lutein (7).

The roots also yielded 9,12-octadecadienoic acid, di-noctyl phthalate, $\quad \beta$-amyrin, kaempferol-7-O-glucoside, kaempferitrin and quercitrin (Joshi et al., 2013). The main sesquiterpenes identified from the root oil of I. coccinea were $\beta$ sesquiphellandrene (17.83\%), ar-curcumene (2.77\%), E- $\alpha$ bergamotene $(2.07 \%), \alpha$-zingiberene $(1.92 \%)$, caryophyllene oxide (1.88\%) and $\delta$-nerolidol (1.44\%) (Srinivasan et al., 2010). Another ornamental plant is Ixora chinensis which is found throughout the Philippines. An infusion of fresh flowers of I. chinensis is used for the treatment of tuberculosis, hemorrhage and headache, while flower decoction is employed for amenorrhea and hypertension (Khare, 2007). I. chinensis yielded D-mannitol, stearic acid, 1,5cyclooctadiene, $\beta$-sitosterol, (10E)-9-oxooctadec-10-en-12-ynoic acid, azelaic acid, and dihydromasticadienolic acid (Ren et al., 2012). The mature seeds of $I$. chinensis afforded an oil having fatty acid composition like palmitic, stearic, oleic, linoleic, crepenynic and ixoric acid (Faten and Zedan, 2003). The leaves and twigs of $I$. chinensis yielded new iridoid glucosides, ixoroside and ixoside (7,8-dehydroforsythide) and geniposidic acid (Takeda et al., 1975).
A study on another species of Ixora, I. parviflora reported that the flowers are used in the treatment of whooping cough and ulcers (Bachheti and Pandey, 2011). The chloroform extract of I. parviflora yielded $\beta$-sitosterol, kaempferol, $\beta$ sitosterol- $\beta$-D-glycoside, kaempferol-7-O-methyl ether (Bachheti and Pandey, 2011). The alcoholic extract of the flowers of $I$. parviflora Vahl afforded chlorogenic acid, apigenin, quercetin, apigenin-7-O- $\beta$-D-glucopyranoside, and quercetin-3-O- $\beta$-Dgalactopyranoside (Gonaid and Sleem, 2006). I. parviflora seed oil was found to contain the following acids: capric (1.3\%), lauric (3.1\%), myristic $(4.7 \%)$, palmitic $(11.4 \%)$, stearic $(11.9 \%)$, arachidic $(2.9 \%)$, behenic $(2.0 \%)$, oleic $(18.7 \%)$, and linoleic (44.0\%) (Dalatabad and Ankalagi, 1982).

The leaves of another Ixora species, I. undulata yielded 1-(R)-phenylethanol $\beta$-gentiobioside, 2-methyl-phenylmethanol $\beta$ gentiobioside, 3,4-dimethylphenol $\beta$-gentiobioside, (5R,6R,Z)-5,6dihydroxy-5,6-dihydro-2H-thiopyran-2-oneO-methyloxime $\beta$-Dglucopyranoside, (5R,6R,Z)-5,6-dihydroxy-5,6-dihydro-2Hthiopyran-2-one O-methyl oxime $\beta$-gentiobioside, kaempferol 3O- $\alpha$-L-rhamnopyranosyl-( $1 \rightarrow 6)$-(4"-trans-p-coumaroyl)- $\beta$-D- 
galactopyranoside, icariside $\mathrm{B}, \quad 7-\mathrm{O}-\alpha$-L-rhamnopyranoside, corchoionoside C, 3-methoxy-4-hydroxyphenol 1-O- $\beta$-Dglucopyranoside, kaempferol 3-O-robinobioside, quercetin 3-Orobinobioside, variabiloside $\mathrm{E}$, and acteoside. Corchoionoside $\mathrm{C}$, quercetin 3-O-robinobioside and variabiloside E showed strong inhibitory activity toward advanced glycation end-products formation with $\mathrm{IC}_{50}$ values of $86.0 \mu \mathrm{M}, 76.6 \mu \mathrm{M}$, and $98.6 \mu \mathrm{M}$, respectively (Sugimoto et al., 2014). Furthermore, the leaves of $I$. undulata Roxb. afforded 7-[( $\beta$-D-glucopyranosyl)oxy]-6-hydroxy2-methoxy-6,7-dihydro-1,3-thiazepine, an alkaloid also known as rubiothiazepine which showed cytotoxic activity against EL4 (Murine Leukemia, $\mathrm{IC}_{50}>100 \mu \mathrm{g} / \mathrm{mL}$ ), cytotoxic and HIV-1 activity against MT-4 and HIV-1IIIB with $\mathrm{CC}_{50}>100 \mu \mathrm{g} / \mathrm{mL}$ and $\mathrm{EC}_{50}>100 \mu \mathrm{g} / \mathrm{mL}$, respectively (Mohammed et al., 2014).

Other Ixora species have been studied for their chemical constituents. The stems of I. amplexicaulis afforded $6 \alpha, 16 \alpha-$ dihyroxy-ent-kaurane, (24R)-6 $\beta$-hydroxy-24-ethyl-cholest-4-en-3one, 7 $\beta$-hydroxysitosterol, maslinic acid, 3,3'-bis(3,4-dihydro-4hydroxy-6-methoxy-2H-1-benzopyran) and protocatechuric acid (Chen et al., 2015). Furthermore, the purified fractions of $I$. javanica flowers that showed antitumor properties contained ferulic acid, pyrocatacheuic acid and caffeic acid (Nair and Panikkar, 1990). Another study reported the isolation of 3-butyn2-ol, 3-butyn-1-ol, amyl nitrite, 2-octyn-1-ol, 1,9-decadiyne and buglyoxylate from I. pavetta Vahl. (Srinivas, K.; Celestin Baboo, 2011). Moreover, the isolation of 3-O- $\beta$-D-glucopyranosyl- $2 \alpha$, $19 \alpha$-dihydroxyurs-12-en-28-oic acid $\beta$-D-glucopyranosyl ester and $2 \alpha, 3 \beta, 19 \alpha$-trihydroxyurs-12-en-28-oic acid $\beta$-D-galactopyranosyl ester from the leaves of $I$. finlaysoniana have been reported (Chauhan et al., 2006). A new flavone glycoside isolated from the stem of $I$. arborea was characterized as chrysin 5-O- $\beta-\mathrm{D}$ xylopyranoside (Chauhan et al., 1984), while another study reported the isolation of apigenin-5-O- $\beta$-D-galactopyranoside (Chauhan et al., 1982). Reviews on the phytochemical and pharmacological activity of genus Ixora have been provided (Kharatet al., 2013; Jiang et al., 2013). This study is part of our research on the chemical constituents of the genus Ixora found in the Philippines. We earlier reported the isolation of two new cycloartenol esters, lupeol fatty ester, lupeol, ursolic acid, oleanolic acid, and $\beta$-sitosterol from the air-dried flowers of $I$. coccinea (Ragasa et al., 2004). We report herein the isolation of syringaresinol (1) pinoresinol (2), isoscopoletin (3), squalene (4), $\beta$-sitosterol (5a), and stigmasterol (5b) from the stems; and 4, 5a, 5b, lupeol (6), and lutein (7) from the leaves of Ixora philippinensis. To the best of our knowledge this is the first report on the isolation of these compounds from I. philippinensis.

\section{MATERIALS AND METHODS}

\section{General Experimental Procedure}

NMR spectra were recorded on a Varian VNMRS spectrometer in $\mathrm{CDCl}_{3}$ at $600 \mathrm{MHz}$ for ${ }^{1} \mathrm{H} \mathrm{NMR}$ and $150 \mathrm{MHz}$ for ${ }^{13} \mathrm{C}$ NMR spectra. Column chromatography was performed with silica gel 60 (70-230 mesh). Thin layer chromatography was performed with plastic backed plates coated with silica gel $\mathrm{F}_{254}$ and the plates were visualized by spraying with vanillin/ $\mathrm{H}_{2} \mathrm{SO}_{4}$ solution followed by warming.

\section{General Isolation Procedure}

A glass column 20 inches in height and 2.0 inches internal diameter was packed with silica gel. The crude extract from the leaves were fractionated by silica gel chromatography using increasing proportions of acetone in $\mathrm{CH}_{2} \mathrm{Cl}_{2} \quad(10 \%$ increment) as eluents. One hundred milliliter fractions were collected. All fractions were monitored by thin layer chromatography. Fractions with spots of the same $R_{f}$ values were combined and rechromatographed in appropriate solvent systems until TLC pure isolates were obtained. A glass column 12 inches in height and 0.5 inch internal diameter was used for the rechromatography. Five milliliter fractions were collected. Final purifications were conducted using Pasteur pipettes as columns. One milliliter fractions were collected.

\section{Sample Collection}

The sample was collected from Bataan, Philippines in October 2013. It was identified as Ixora philippinensis Merr. at the Jose Vera Santos Herbarium, Institute of Biology, University of the Philippines, Diliman, Quezon City.

\section{Isolation of the Chemical Constituents of the Stems}

The air-dried stems (218 g) of I. philippinensis were ground in an osterizer, soaked in $\mathrm{CH}_{2} \mathrm{Cl}_{2}$ for three days, and then filtered. The filtrate was concentrated under vacuum to afford a crude extract ( $3.1 \mathrm{~g}$ ) which was chromatographed using increasing proportions of acetone in $\mathrm{CH}_{2} \mathrm{Cl}_{2}(10 \%$ increment) as eluents. The $\mathrm{CH}_{2} \mathrm{Cl}_{2}$ fraction was rechromatographed $(3 \times)$ in $1 \% \mathrm{EtOAc}$ in petroleum ether to afford 4 (12 mg). The $30 \%$ acetone in $\mathrm{CH}_{2} \mathrm{Cl}_{2}$ fraction was rechromatographed $(2 \times)$ in $15 \%$ EtOAc in petroleum ether to afford a mixture of $\mathbf{5 a}$ and $\mathbf{5 b}(2 \mathrm{mg})$ after washing with petroleum ether. The $50 \%$ acetone in $\mathrm{CH}_{2} \mathrm{Cl}_{2}$ fraction was rechromatographed $(3 \times)$ using $\mathrm{CH}_{3} \mathrm{CN}: \mathrm{Et}_{2} \mathrm{O}: \mathrm{CH}_{2} \mathrm{Cl}_{2}$ (1:1:8 by volume ratio) to afford $3(1 \mathrm{mg})$ after trituration with petroleum ether. The $60 \%$ acetone in $\mathrm{CH}_{2} \mathrm{Cl}_{2}$ fraction was rechromatographed (3 $\times$ ) using $\mathrm{CH}_{3} \mathrm{CN}: \mathrm{Et}_{2} \mathrm{O}: \mathrm{CH}_{2} \mathrm{Cl}_{2}(1.5: 1.5: 7$ by volume ratio) to afford $2(3 \mathrm{mg})$ after trituration with petroleum ether. The $70 \%$ acetone in $\mathrm{CH}_{2} \mathrm{Cl}_{2}$ fraction was rechromatographed $(4 \times)$ using $\mathrm{CH}_{3} \mathrm{CN}: \mathrm{Et}_{2} \mathrm{O}: \mathrm{CH}_{2} \mathrm{Cl}_{2}$ (1.5:1.5:7 by volume ratio) to afford 1 (3 $\mathrm{mg}$ ) after trituration with petroleum ether.

\section{Isolation of the Chemical Constituents of the Leaves}

The air-dried leaves $(605 \mathrm{~g})$ of I. philippinensis were ground in an osterizer, soaked in $\mathrm{CH}_{2} \mathrm{Cl}_{2}$ for three days, and then filtered. The filtrate was concentrated under vacuum to afford a crude extract (18.2 g) which was chromatographed using increasing proportions of acetone in $\mathrm{CH}_{2} \mathrm{Cl}_{2}$ (10\% increment) as 
eluents. The $\mathrm{CH}_{2} \mathrm{Cl}_{2}$ fraction was rechromatographed $(3 \times)$ in $1 \%$ EtOAc in petroleum ether to afford $4(18 \mathrm{mg})$. The $30 \%$ acetone in $\mathrm{CH}_{2} \mathrm{Cl}_{2}$ fraction was rechromatographed $(4 \times)$ in $15 \%$ EtOAc in petroleum ether to afford 6 (3 $\mathrm{mg}$ ) after washing with petroleum ether. The $40 \%$ acetone in $\mathrm{CH}_{2} \mathrm{Cl}_{2}$ fraction was rechromatographed $(2 \times)$ in $20 \%$ EtOAc in petroleum ether to afford a mixture of $\mathbf{5 a}$ and $5 \mathbf{b}(4 \mathrm{mg})$ after washing with petroleum ether. The 50\% acetone in $\mathrm{CH}_{2} \mathrm{Cl}_{2}$ fraction was rechromatographed $(3 \times)$ in $\mathrm{CH}_{3} \mathrm{CN}: \mathrm{Et}_{2} \mathrm{O}: \mathrm{CH}_{2} \mathrm{Cl}_{2}(0.5: 0.5: 9$, v/v) to yield $7(7 \mathrm{mg})$ after washing with petroleum ether, followed by $\mathrm{Et}_{2} \mathrm{O}$.

\section{Syringaresinol (1)}

${ }^{1} \mathrm{H}$ NMR (600 MHz, $\left.\mathrm{CDCl}_{3}\right): \delta 3.07$ (m, H-2, H-5), 4.71 (d, $J=4.2 \mathrm{~Hz}, \mathrm{H}-1, \mathrm{H}-4), 4.26$ (dd, $J=9,4.2 \mathrm{~Hz}, \mathrm{H}-3 \mathrm{a}, \mathrm{H}-6 \mathrm{a})$, 3.89 (dd, $J=6.6,4.2 \mathrm{~Hz}, \mathrm{H}-3 \mathrm{~b}, \mathrm{H}-6 \mathrm{~b}$ ), 6.56 (s, H-2', H-6', H-2", H-6"), 3.89 (s, 3'-OCH 3,5 '-OCH 3,3 '--OCH 3 , 5"-OCH ${ }_{3}$ ), 5.57 (s, 4'$\mathrm{OH}, 4 "-\mathrm{OH}) ;{ }^{13} \mathrm{C}$ NMR $\left(150 \mathrm{MHz}, \mathrm{CDCl}_{3}\right): \delta 86.07$ (C-1, C-4), 54.35 (C-2, C-5), 71.80 (C-3, C-6), 132.08 (C-1', C-1"), 102.65 (C-2', C-6', C-2", C-6"), 147.14 (C-3', C-5', C-3", C-5"), 134.26 (C-4', C-4"), 56.37 (3'- $\mathrm{OCH}_{3}, 5^{\prime}-\mathrm{OCH}_{3}, 3$ "- $\left.\mathrm{OCH}_{3}, 5^{\prime \prime}-\mathrm{OCH}_{3}\right)$.

\section{Pinoresinol (2)}

${ }^{1} \mathrm{H}$ NMR $\left(600 \mathrm{MHz}, \mathrm{CDCl}_{3}\right): \delta 4.72(\mathrm{~d}, J=4.2 \mathrm{~Hz}, \mathrm{H}-1$, H-4), 3.08 (1H, m, H-2, H-5), 3.86 (dd, $J=3.6,9.0 \mathrm{~Hz}, \mathrm{H}-3 \mathrm{~b}, \mathrm{H}-$ 6b), 4.25 (dd, $J=7.2,9.0 \mathrm{~Hz}, \mathrm{H}-3 \mathrm{a}, \mathrm{H}-6 \mathrm{a}), 6.88$ (d, $J=1.8 \mathrm{~Hz}, \mathrm{H}-$ 2', H-2"), 6.87 (d, $J=7.8 \mathrm{~Hz}, \mathrm{H}-5$ ', H-5"), 6.82 (dd, $J=8.4,1.8$ $\mathrm{Hz}, \mathrm{H}-6$ ', H-6"), 3.93 (s, 3'-OCH 3 , 3"-OCH 3 ); ${ }^{13} \mathrm{C}$ NMR $(150 \mathrm{MHz}$, $\left.\mathrm{CDCl}_{3}\right): \delta 85.86$ (C-1, C-4), 54.15 (C-2, C-5), 71.66 (C-3, C-6), 132.90 (C-1', C-1"), 108.56 (C-2', C-2"), 146.68 (C-3', C-3"), 145.22 (C-4', C-4"), 114.24 (C-5', C-5"), 118.96 (C-6', C-6"), $55.95\left(3^{\prime}-\mathrm{OCH}_{3}, 3\right.$ '- $\left.-\mathrm{OCH}_{3}\right)$.

\section{Isoscopoletin (3)}

${ }^{1} \mathrm{H}$ NMR $\left(600 \mathrm{MHz}, \mathrm{CDCl}_{3}\right): \delta 6.25(\mathrm{~d}, J=9.0 \mathrm{~Hz}, \mathrm{H}-3)$, 7.57 (d, $J=9.0 \mathrm{~Hz}, \mathrm{H}-4$ ), 6.83 (brs, H-5), 6.90 (brs, H-8), 6.09 (brs, - $\mathrm{OH}), 3.94\left(\mathrm{~s},-\mathrm{OCH}_{3}\right) \cdot{ }^{13} \mathrm{C}$ NMR $\left(150 \mathrm{MHz}, \mathrm{CDCl}_{3}\right): \delta$ 161.43 (C-2), 111.49 (C-3), 143.26 (C-4), 107.42 (C-5), 149.65 (C-6), 143.96 (C-7), 103.19 (C-8), 150.26 (C-9), 113.45 (C-10), $56.40\left(-\mathrm{OCH}_{3}\right)$.

\section{Squalene (4)}

${ }^{1} \mathrm{H}$ NMR $\left(600 \mathrm{MHz}, \mathrm{CDCl}_{3}\right): \delta$ 5.07-5.13 $(6 \mathrm{H},=\mathrm{CH})$, $1.58\left(18 \mathrm{H}\right.$, allylic $\mathrm{CH}_{3}$, cis $), 1.66\left(6 \mathrm{H}\right.$, allylic $\mathrm{CH}_{3}$, trans $)$, 1.94$2.08\left(20 \mathrm{H}\right.$, allylic $\left.\mathrm{CH}_{2}\right) .{ }^{13} \mathrm{C}$ NMR $\left(150 \mathrm{MHz}, \mathrm{CDCl}_{3}\right): \delta 25.69(\mathrm{C}-$ 1), 131.26 (C-2), 124.27 (C-3), 26.66 (C-4), 39.75 (C-5), 134.90 (C-6), 124.30 (C-7), 26.76 (C-8), 39.72 (C-9), 135.10 (C-10), 124.40 (C-11), 28.27 (C-12), 17.67 (C-2'), 16.04 (C-6'), 15.99 (C$\left.10^{\prime}\right)$.

\section{及-Sitosterol (5a)}

${ }^{1} \mathrm{H}$ NMR (600 MHz, $\left.\mathrm{CDCl}_{3}\right): \delta 3.50(\mathrm{~m}, \mathrm{H}-3), 2.26,2.21$ $\left(\mathrm{H}_{2}-4\right), 5.33$ (dd, $\left.J=5.0,2.0 \mathrm{~Hz}, \mathrm{H}-6\right), 0.66\left(\mathrm{~s}, \mathrm{CH}_{3}-18\right), 0.99$ (s, $\left.\mathrm{CH}_{3}-19\right), 0.90$ (d, $\left.J=7.0 \mathrm{~Hz}, \mathrm{CH}_{3}-21\right), 0.79$ (d, $J=7.0 \mathrm{~Hz}, \mathrm{CH}_{3^{-}}$
26), $0.82\left(\mathrm{~d}, J=7.0 \mathrm{~Hz}, \mathrm{CH}_{3}-27\right), 0.85$ (t, $\left.J=7.0 \mathrm{~Hz}, \mathrm{CH}_{3}-29\right)$. ${ }^{13} \mathrm{C}$ NMR $\left(150 \mathrm{MHz}, \mathrm{CDCl}_{3}\right): \delta 37.24(\mathrm{C}-1), 31.64(\mathrm{C}-2), 71.80$ (C-3), 42.28 (C-4), 140.74 (C-5), 121.71 (C-6), 31.88 (C-7), 31.90 (C-8), 50.14 (C-9), 36.49 (C-10), 21.07 (C-11), 39.75 (C-12), 42.20 (C-13), 56.75 (C-14), 24.35 (C-15), 28.24 (C-16), 56.03 (C17), 11.97 (C-18), 19.38 (C-19), 36.13 (C-20), 18.76 (C-21), 33.93 (C-22), 26.04 (C-23), 45.81 (C-24), 29.13 (C-25), 19.02 (C-26), 19.81 (C-27), 23.05 (C-28), 11.85 (C-29).

\section{Stigmasterol (5b)}

${ }^{1} \mathrm{H}$ NMR (600 MHz, $\mathrm{CDCl}_{3}$ ): $\delta 3.50$ (m, H-3), 5.33 (dd, $J$ $=1.8,4.8 \mathrm{~Hz}, \mathrm{H}-6), 0.68\left(\mathrm{~s}, \mathrm{CH}_{3}-18\right), 0.99\left(\mathrm{~s}, \mathrm{CH}_{3}-19\right), 1.01(\mathrm{~d}, J=$ $\left.6.6 \mathrm{~Hz}, \mathrm{CH}_{3}-21\right), 5.13$ (dd, $\left.J=8.4,15.0 \mathrm{~Hz}, \mathrm{H}-22\right), 5.00$ (dd, $J=$ 9.0, $15.0 \mathrm{~Hz}, \mathrm{H}-23), 0.84$ (d, $\left.J=6.6 \mathrm{~Hz}, \mathrm{CH}_{3}-26\right), 0.83$ (d, $J=6.6$ $\left.\mathrm{Hz}, \mathrm{CH}_{3}-27\right), 0.80\left(\mathrm{t}, J=6.6 \mathrm{~Hz}, \mathrm{CH}_{3}-29\right) .{ }^{13} \mathrm{C}$ NMR $(150 \mathrm{MHz}$, $\left.\mathrm{CDCl}_{3}\right): \delta 37.24(\mathrm{C}-1), 31.64(\mathrm{C}-2), 71.80(\mathrm{C}-3), 42.28$ (C-4), 140.74 (C-5), 121.71 (C-6), 31.88 (C-7), 31.90 (C-8), 50.14 (C-9), 36.49 (C-10), 21.07 (C-11), 39.66 (C-12),42.20 (C-13), 56.75 (C14), 24.35 (C-15), 28.91 (C-16), 55.93 (C-17), 12.03 (C-18), 19.38 (C-19), 40.49 (C-20), 21.07 (C-21), 138.31 (C-22), 129.25 (C-23), 51.22 (C-24), 31.90 (C-25), 21.20 (C-26), 18.97 (C-27), 25.40 (C28), 12.24 (C-29).

\section{Lupeol (6)}

${ }^{1} \mathrm{H}$ NMR $\left(600 \mathrm{MHz}, \mathrm{CDCl}_{3}\right): \delta 4.65(\mathrm{~d}, J=2.4 \mathrm{~Hz}, \mathrm{H}-$ 29b), 4.54 (d, J = 2.4 Hz, H-29a), 3.18 (H-3), 0.95 (s, H3-23), 0.74 (s, $\left.\mathrm{H}_{3}-24\right), 0.77$ ( $\left.\mathrm{s}, \mathrm{H}_{3}-25\right), 0.92$ (s, $\left.\mathrm{H}_{3}-26\right), 1.01$ (s, $\mathrm{H}_{3}-27$ ), 0.81 (s, $\left.\mathrm{H}_{3}-28\right), 1.66\left(\mathrm{~s}, \mathrm{H}_{3}-30\right) .{ }^{13} \mathrm{C}$ NMR $\left(150 \mathrm{MHz}, \mathrm{CDCl}_{3}\right): \delta 38.85$ (C1), 27.40 (C-2), 79.01 (C-3), 38.69 (C-4), 55.28 (C-5), 17.99 (C6), 34.26 (C-7), 40.82 (C-8), 50.42 (C-9), 37.16 (C-10), 20.92 (C11), 25.12 (C-12), 38.04 (C-13), 42.82 (C-14), 27.40 (C-15), 35.57 (C-16), 47.98 (C-17), 48.29 (C-18), 47.98 (C-19), 150.99 (C-20), 29.83 (C-21), 39.99 (C-22), 27.98 (C-23), 15.36 (C-24), 16.11 (C25), 15.96 (C-26), 14.54 (C-27), 18.31 (C-28), 109.31 (C-29), 19.29 (C-30).

\section{Lutein (7)}

${ }^{1} \mathrm{H}$ NMR $\left(600 \mathrm{MHz}, \mathrm{CDCl}_{3}\right): \delta 1.05$ (s, 2 ring $\mathrm{A} \mathrm{CH}_{3}$ ), 0.83 (s, ring $\mathrm{B} \mathrm{CH}_{3}$ ), 0.98 (s, ring $\mathrm{B} \mathrm{CH}_{3}$ ), 1.60 (allylic $\mathrm{CH}_{3}$ ), 1.71 (allylic $\mathrm{CH}_{3}$ ), 1.89 (allylic $\mathrm{CH}_{3}$ ), 1.91 (allylic $\mathrm{CH}_{3}$ ), 1.94 (2 allylic $\left.\mathrm{CH}_{3}\right), 1.45,1.75\left(\mathrm{CH}_{2}\right), 1.35,1.85\left(\mathrm{CH}_{2}\right), 2.35,2.00$ (allylic $\left.\mathrm{CH}_{2}\right)$, 2.38 (allylic $\mathrm{CH}$ ), 4.23 (br s, $\mathrm{CHOH}), 3.98(\mathrm{~m}, \mathrm{CHOH}), 5.52$ (br s, $=\mathrm{CH}), 5.41(\mathrm{dd}, J=9.6,15.0 \mathrm{~Hz},=\mathrm{CH}), 6.56-6.65,6.33(\mathrm{dd}, J=$ 15.0, 3.0 Hz), 6.23 (br d, $J=9.6 \mathrm{~Hz}), 6.09-6.14(=\mathrm{CH}) .{ }^{13} \mathrm{C} \mathrm{NMR}$ $\left(150 \mathrm{MHz}, \mathrm{CDCl}_{3}\right): \delta 37.12(\mathrm{C}-1), 48.41(\mathrm{C}-2), 65.11(\mathrm{C}-3), 42.53$ (C-4), 126.15 (C-5), 138.02 (C-6), 125.57 (C-7), 138.71 (C-8), 135.69 (C-9), 131.29 (C-10), 124.92 (C-11), 137.56 (C-12), 136.41 (C-13), 132.57 (C-14), 130.08 (C-15), 28.72 (C-16), 30.25 (C-17), 21.61 (C-18), 12.75 (C-19, C-20), 34.02 (C-1'), 44.62 (C$\left.2^{\prime}\right), 65.94$ (C-3'), 124.44 (C-4'), $137.72\left(\mathrm{C}-5^{\prime}\right), 55.0\left(\mathrm{C}^{\prime} 6^{\prime}\right), 128.71$ (C-7'), 130.80 (C-8'), 135.06 (C-9'), 137.56 (C-10'), 124.80 (C11'), 137.75 (C-12'), 136.48 (C-13'), 132.57 (C-14'), 130.08 (C- 
15'), 24.27 (C-16'), 29.49 (C-17'), 22.89 (C-18'), 13.19 (C-19'), $12.81\left(\mathrm{C}-20^{\prime}\right)$.

\section{RESULTS AND DISCUSSION}

Silica gel chromatography of the dichloromethane extract of the leaves of I. philippinensis yielded 1-7. The structures of 1 and $\mathbf{3}$ were elucidated by extensive 1D and 2D NMR spectroscopy and confirmed by comparison of their NMR data with those reported in the literature for syringaresinol (1) (Monthong et al., 2011) and isoscopoletin (3) (Ragasa et al., 2014a).

The structures of $\mathbf{2}$ and 4-7 were identified by comparison of their NMR data with those reported in the literature for pinoresinol (2) (Ragasa et al., 2000), squalene (4) (Ragasa $e t$ al., 2015; Ragasa et al., 2014b), $\beta$-sitosterol (5a) (Ragasa et al., 2014c; Ebajo et al., 2015), stigmasterol (5b) (Ragasa et al., 2014c; Ebajo et al., 2015), lupeol (6) (Tsai et al., 2012; Ebajo et al., 2015), and lutein (7) (Ragasa et al., 2015; Ebajo et al., 2015).

These results indicate that Ixora philippinensis share similar chemical characteristics with other members of the genus Ixora which contained similar classes of compounds: I. coccinea sterols, triterpenes, and aromatic compounds; I. parviflora sterols and aromatic compounds; I. undulata, I. javanica, I. arborea - aromatic compounds; I. amplexicaulis - aromatic compounds and triterpene; and I. finlaysoniana - triterpenes. The differences may be due to the different polarities of the solvents used for extraction and the different parts of the plants studied: $I$. philippinensis - stems and leaves; I. parviflora - aerial parts; I. undulate - stems; I. amplexicaulis - stems and flowers; I. javanica - flowers; I. finlaysoniana - leaves; and I. arborea - stems.

\section{CONCLUSION}

Ixora philippinensis is an ornamental plant endemic to the Philippines with no reported chemical and biological activity studies. The dichloromethane extracts of this plant afforded 1-5b from the stems, while the leaves yielded 4-7. I. philippinensis contained sterols, triterpene, and aromatic compounds which belong to the same classes of compounds found in other Ixora species.

\section{ACKNOWLEDGEMENT}

A research grant from the De La Salle University Science Foundation through the University Research Coordination Office is gratefully acknowledged.

\section{REFERENCES}

Bachheti RK, Pandey DP. Phytochemical analysis of aerial parts of Ixora parviflora. Int J Chem Tech Res 2011; 3(3):1028-1032.

Bose S, Maji S, Chakraborty P. Quercitrin from Ixora coccinea leaves and its anti-oxidant activity. J Pharma Sci Tech 2013; 2(2):72-74.
Chauhan D, Gupta A, Srivastava N, Singh J. Constituents from Ixora finlaysoniana. J Indian Chem Soc 2006; 83(3):248-250.

Chauhan JS, Kumar S, Chaturvedi R. A flavone glycoside from the stem of Ixora arborea. Phytochem 1984; 23(10):2404-5.

Chauhan JS, Kumar S, Chaturvedi R. Structure of a new flavone glycoside from Ixora arborea stem. Curr Sci 1982; 51(22):106970 .

Chen L, Zhan R, Jiang J, Zhang Yan, Dong Y, Chen Y. A new ent-kaurane diterpenoid from Ixora amplexicaulis. Nat Prod Res 2015; Ahead of Print.

Daulatabad CD, Ankalagi RF. Minor seed oils. I. Component fatty acids of some seed oils. J Food Sci Tech 1982; 19(3):112-13.

Ebajo Jr V, Shen C-C, Ragasa CY. Terpenoids and sterols from Hoya multiflora Blume. J Appl Pharm Sci 2015; 5(4):33-39.

Elumalai A, Chinna E. Phytochemical and pharmacological profile of Ixora coccinea Linn. Int J of Pharm Life Sci 2012;3(3):15631567

Faten MM, Zedan ZI. Phytochemical Study of Ixora finlaysoniana Wall. ex. G. Dongrowing in Egypt. Bull Pharm Sci 2003; 26(1):91-96.

Ghazali N, Abdullah NA, Abu Bakar A, Mohamad, NK. GCMS analysis of some bioactive components in the root extract of Ixora coccinea Linn. Int J Pharm Bio Sci 2014; 5(3):197-203.

Gonaid MH, Sleem AA. Chemical and biological studies of Ixora parviflora Vahl. flowers. Egyptian J Biomed Sci 2006; 21:70-82.

Idowu TO, Ogundaini AO, Salau AO, Obuotor EM, Bezabih M, Abegaz BM. Doubly linked, A-type proanthocyanidin trimer and other constituents of Ixora coccinea leaves and their antioxidant and antibacterial properties. Phytochem 2010; 71(17-18):2092-2098.

Ikram A, Versiani MA, Shamshad S, Ahmed SK, Ali ST, Faizi S. Ixorene, a new dammarane triterpene from the leaves of Ixora coccinea Linn. Rec Nat Prod 2013; 7(4):302-306.

Jiang Z-o, Huang P, Wei G-n. Zhongnan Yaoxue. 2013; 11(4): 284-289

Joshi AB, Surlikar PM, Bhobe M. Ixora coccinea Linn: phytochemical investigation. Int J Res Pharm Chem 2013, 3(3), 691-696.

Kharat AR, Nambiar VV, Tarkasband YS, Pujari RR. A review on phytochemical and pharmacological activity of genus Ixora. Int J Res Pharm Chem 2013; 3(3):628-635.

Khare CP. Indian Medicinal Plants, Springer private limited; 2007;338-339.

Latha PG, Nayar MNS, Singh OV, George V, Panikkar KR, Pushpangadan P. Isolation of antigenotoxic ursolic acid from Ixora coccinea flowers. Actualidades Biologicas 2001;23:21-24.

Latha PG, Panikar KR. Cytotoxic and antitumour principles from Ixora coccinea flowers. Cancer Lett 1998; 130:197-202.

Latha PG, Panikar KR. Chemoprotective effect of Ixora coccinea L. flowers on cisplatin induced toxicity in mice. Phytother Res 2001;15:364-366.

Latha PG, Panikar KR. Protective effect of Ixora coccinea flower extract on cyclophosphamide induced toxicity in mice. Phytother Res 1999;13:517-520.

Merrill ED. Ixora philippinensis Merr. Philipp J Sci C 1910; $5: 238$.

Mohammed MMD, Ibrahim NA, Chen M, Zhai L. Rubiothiazepine a novel unusual cytotoxic alkaloid from Ixora undulata Roxb. leaves. Nat Prod Chem Res 2014; 2(2):1-4.

Monthong W, Pitchuanchom S, Nuntasaen N, Pompimon W. (+)-Syringaresinol lignan from new species Magnolia thailandica. Amer J Appl Sci 2011; 8(12):1268-1271.

Nair SC, Panikkar KR. Antitumour principles from Ixora javanica. Cancer Lett 1990; 49(2):121-6.

Quisumbing E. 1978. Medicinal Plants of the Philippines, pp. 372-377. Bureau of Printing, Manila.

Ragasa CY, Tan MCS, Chiong I, Shen C-C. Chemical constituents of Muntingia calabura. Der Pharma Chemica 2015; 7(5):136141. 
Ragasa CY, Ng VAS, De Los Reyes MM, Mandia EH, Shen CC. Triterpenes and a coumarin derivative from Kibatalia gitingensis (Elm.) Woodson. Der Pharma Chemica 2014a; 6(5):360-364.

Ragasa CY, Ng VAS, De Los Reyes MM, Mandia EH, Oyong GG, Shen C-C. Chemical constituents and cytotoxicity of the leaves of Dysoxylum gaudichaudianum (A. Juss.) Miq. Der Pharma Chemica 2014b; 6(5):182-187.

Ragasa CY, Ng VAS, De Los Reyes MM, Mandia EH, Shen CC. Chemical constituents of Pipturus arborescens. Der Pharmacia Lettre 2014c; 6(6):35-42.

Ragasa CY, Hofilena JG, Rideout JA. Lignans from Gliricidia sepium. ACGC Chem Res Commun 2000; 10:52-60.

Zachariah R; Nair CRS, Velayudha PP. Antiinflammatory and antimitotic activities of lupeol isolated from the leaves of Ixora coccinea Linn. Indian J Pharm Sci 1994; 56:129-32.

Takeda Y, Nishimura H, Inouye H. Studies on monoterpene glucosides and related natural products. 28. Two new iridoid glucosides from Ixora chinensis. Phytochem 1975; 14(12):2647-50.

Tsai P-W, de Castro-Cruz K, Shen C-C, Ragasa CY. Chemical constituents of Broussonetia luzonicus. Phoog J 2012; 4(31):1-4.

Ren S-s, Luo Peng, Pan W-g, Liang C-y, Li Y-h, Zhou W. Study on chemical constituents from Ixora chinensis. Zhongcaoyao, 2012; 43(11):2116-2119.

Srinivasan GV, Sharanappa P, Udayan PS, LeelaNK, Vijayan KK. Chemical composition and antimicrobial activity of the essential oil of Ixora coccinea L. root. J Med Arom Plant Sci 2010;32(1): 27-30.
Srinivas K, Celestin Baboo RV. GC-MS study of Ixora pavetta Vahl. International J Pharm Sci Res 2011; 2(8):2100-2102.

Sugimoto S, Matsunami K, Wanas AS, Mizuta T, Kamel MS, Otsuka H. Structure elucidation of secondary metabolites isolated from the leaves of Ixora undulata and their inhibitory activity toward advanced glycation end-products formation. Phytochem 2014; 108:18995.

Versiani MA, Ikram A, Khalid S, Faizi S, Tahiri IA. Ixoroid: a new triterpenoid from the flowers of Ixora coccinea. Nat Prod Commun 2012; 7(7):831-834.

Ysrael MC, van Valkenburg JLCH, 1999. Ixora L.Record from Proseabase. de Padua LS, Bunyapraphatsara N, Lemmens RHMJ. (Editors). PROSEA (Plant Resources of South-East Asia) Foundation, Bogor, Indonesia. http://www.proseanet.org. Accessed on 04-Jun-2015.

\section{How to cite this article:}

Consolacion Ragasa, Maria Carmen Tan, Dalton Fortin, ChienChang Shen. Chemical Constituents of Ixora philippinensis Merr. J App Pharm Sci, 2015; 5 (09): 062-067. 